\title{
PENGEMBANGAN PERANGKAT PEMBELAJARAN SAINTIFIK DENGAN MODEL PROBLEM BASED LEARNING MELALUI PENALARAN INDUKTIF PADA TOPIK LAJU REAKSI
}

\author{
I. B. N. Sudria; I Gusti Lanang Wiratma; Lysa Kristina Br Sembiring \\ Universitas Pendidikan Ganesha
}

\section{A R T I C L E I N F O}

Article history: Received 7 Januari 2019 Received in revised form 26 Januari 2019 Accepted 19 Maret 2019 Available online 30 April 2019

Kata Kunci: model pembelajaran problem based learning, laju reaksi, penalaran induktif, pendekatan saintifik, dan perangkat pembelajaran

\begin{abstract}
Abstrak
Tujuan dari penelitian dan pengembangan pendidikan ini adalah untuk (1) mengembangkan dan mendeskripsikan karakteristik perangkat pembelajaran yang selaras dengan model problem based learning melalui penalaran induktif pada topik laju reaksi. (2) mendeskripsikan validitas dan tingkat keterbacaan, dan (3) mengetahui keefektifan dari perangkat pembelajaran melalui uji coba pendahulu. Penelitian dan pengembangan (R\&D) ini mengikuti model Borg dan Gall (1989) yang dibatasi pada tahap uji coba pendahuluan. Hasil penelitian dan pengembangan ini mampu mewujudkan perangkat pembelajaran model problem based learning dengan efektif. Perangkata pembelajaran yang dikembangkan dapat menghasilkan perangkat yang konsisten dan selaras mengikuti model problem based learning melalui penalaran induktif dengan pendekatan saintifik, memiliki tingkat validitas dan uji keterbacaan sangat baik dan baik., mendapatkan hasil belajar yang signifikan dengan nilai Normalitas Gain Score 0,55 dengan kategori sedang secara keseluruhan, penilian perindikator termasuk kategori tinggi untuk satu indikator dan sedang untuk enam indikator, peningkatan rata-rata pretest 23,27 menjadi ratarata posttest 65,18, penilian aktivitas siswa dengan pendekatan saintifik $5 \mathrm{M}$ dilihat dari penilian LKS secara umum meningkat, dan hasil tanggapan siswa terhadap proses pembelajaran dengan model problem based learning malalui penalaran induktif tergolong baik.
\end{abstract}

\begin{abstract}
The purpose of this research and development education are to (1) develop and describe characteristics of learning devices that are in harmony with the problem based learning model through inductive reasoning on the topic of reaction rates, (2) describing the validity and readability level, and (3) knowing the effectiveness of learning device through a preliminary trial. This research and development (R \& D) follows the Borg and Gall (1989) model which was limited to the preceding trial stage. The results of this research and development are able to realize a problem based learning model learning device effectively. It can, the results show that learning devices are consistent and harmonious can follow the problem based learning model through inductive reasoning with a scientific approach, have a very good and good level of validity and readability test, get significant learning outcomes with nilia Normality Gain Score 0.55 with categories is being Indicator evaluators are included in the high category for one indicator and medium for six indicators. The increase in the average pretest 23.27 becomes the average posttest 65.18 , the assessment of student activity with the scientific approach $5 \mathrm{M}$ seen from the LKS assessment generally
\end{abstract}


increases, and the results of student responses to the learning process with problem based learning models through inductive reasoning are good .

Keywords: problem based learning model, reaction rate, inductive reasoning, saintific approach, and learning tool

\section{PENDAHULUAN}

Pada hakekatnya belajar sains cendrung belajar penemuan dimana mencakup keterampilan proses sains dan sikap ilmiah yang diperlukan untuk memperoleh dan mengembangkan pengetahuan (Carin \& Sund, 1975). Belajar penemuan pada dasarnya bisa dilakukan dengan penalaran induktif dan penalaran deduktif. Pembelajaran dengan penalaran induktif yang taat asas ini membawa siswa dapat belajar secara bermakna, bukan hafalan. Penalaran deduktif cendrung sebagai perspektif positivistik dan penalaran induktif cendrung sebagai perspektif fenomenologis (Thomond, 2004). Pada pebelajar pemula berpikir dengan penalaran induktif dan deduktif sangat sulit dipahami dibandingkan dengan pebelajar dewasa yang sudah terbiasa dengan penalaran berfikir induktif dan deduktif, secara langsung pebelajar dewasa akan mampu mengkombinasikan penalaran berfikir tersebut ketika dihadapkan pada suatu masalah.

Penalaran induktif merupakan penalaran belajar yang dimulai dari sesuatu yang bersifat khusus menuju sebuah kesimpulan (generalisasi). Belajar secara induktif merupakan gaya belajar manusia secara alami (Felder \& Silverman 1998). Pada dasarnya penalaran induktif ini melibatkan identifikasi masalah sebab-akibat, perumusan data-based hypothesis (tentative hypothesis) terhadap jawaban masalah tersebut, merencanakan serta melakukan eksperimen pembuktian, analisis hasil eksperimen, penyimpulan, dan penerapan situasi baru (Lawson, 1989).

Kebiasaan belajar siswa pemula yang menggabungkan penalaran induktif maupun deduktif akan cendrung menghafal dan dapat menyebabkan siswa kesulitan memahami materi dalam waktu jangka panjang dan perpengaruh terhadap rendahnya kualitas pembelajaran sains (Sudria, 2016). Oleh karena itu pembinaan keterampilan bernalar secara induktif pada pebelajar pemula (siswa sekolah menengah) dengan pendekatan saintifik memerlukan pembiasaan sesuai dengan penalarn induktif. Hal ini memerlukan dukungan perangkat pembelajaran seperti rencana pelaksanaan pembelajaran (RPP), lembar kerja siswa (LKS), teks materi pelajaran yang konsisten serta selaras denan alur penalaran induktif.

Belajar penemuan berdasarkan pendekatan saintifik melalui penalaran induktif dapat diimplementasikan dengan variasi model pembelajaran sesuai dengan amanat kurikulum 2013. Model pembelajaran merupakan salah satu upaya untuk memudahkan penyampaian materi yang akan diajarkan untuk memenuhi gaya belajar setiap siswa dalam merespon suatu materi pembelajaran. Menurut Wahab (2001: 52) model pembelajaran adalah sebuah perencanaan pengajaran yang menggambarkan proses yang ditempuh pada proses belajar mengajar agar dicapai perubahan spesifik pada perilaku siswa seperti yang diharapkan. Pembelajaran yang efektif memebutuhkan model pembelajaran yang mendukung penyampaian isi dan ketercapaian tujuan pembelajaran. Berdasarkan penalaran induktif model pembelajaran yang selaras adalah model pembelajaran problem based learning.

Model problem based leraning adalah seperangkat model mengajar yang menggunakan masalah sebagai fokus utama untuk mengembangkan keterampilan pemecahan masalah, materi, dan pengaturandiri (Hmelo-Silver, 2004; serafino \& Cicchelli, 2005, Egen dan Kauchak, 2012:307). PBL merupakan suatu pendekatan pembelajaran yang menggunakan masalah dunia nyata sebagai suatu konteks bagi pesertas didik untuk belajara tentang cara berpikir kritis dan keterampilan pemecahan masalah, serta untuk memperoleh pengetahuan dan konsep yang esensial dari materi pelajaran. Karakteristik model PBL menurut Rusman (2010:232) adalah sebagai berikut: a. Permasalahan menjadi starting point dalam belajar, Permasalahan yang diangkat adalah permasalahan yang ada di dunia nyata yang tidak terstruktur. c. Permasalahan membutuhkan perspektif ganda (multiple perspective). d. Permasalahan menantang pengetahuan yang dimiliki oleh siswa, sikap, dan kompetensi yang kemudian membutuhkan identifikasi kebutuhan belajar dan bidang baru dalam belajar. e. Belajar pengarahan diri menjadi hal yang utama. $\mathrm{f}$. Pemanfaatan sumber pengetahuan yang beragam, penggunaannya, dan evaluasi sumber informasi merupakan proses yang esensial dalam problem based learning. g. Belajar adalah kolaboratif, komunikasi, dan kooperatif. h. Pengembangan keterampilan inquiry dan pemecahan masalah sama pentingnya dengan penguasaan isi pengetahuan untuk mencari solusi dari sebuah permasalahan. i. sintesis dan integrasi dari sebuah proses belajar. j. Problem based learning melibatkan evaluasi dan review pengalaman siswa dan proses belajar. Tiga hasil belajar (outcomes) yang diperoleh siswa yang diajar dengan problem based learning menurut (Arends, 2008) yaitu: 1. Inkuiri dan keterampilan melakukan pemecahan masalah, 
2. Belajar model peraturan orang dewasa (adult role behaviors), dan 3. Keterampilan belajar mandiri (skills for independent learning). Menurut Arends (2008) langkah-langkah dalam melaksanakan PBL ada 5 fase yaitu (1) mengoientasikan siswa pada masalah; (2) mengorganisasikan siswa untuk belajar; (3) membantu investigasi mandiri dan berkelompok; (4) mengembangkan dan menyajikan hasil karya; (5) menganalisis dan mengevaluasi proses pemecahan masalah.

Penalaran induktif adalah belajar yang dimulai dari gaya belajar secara alami dan belajar berdasarkan fenomena-fenomena yang terjadi didunia nyata. Penlaran induktif ini cendrung memiliki hal yang sama dengan model problem based learning dimana pembelajaran model ini memfokuskan masalah sebegai kunci utama dalam peembelajaran. Masalah-masalah yang muncul adalah masalah yang terjadi di dunia nyata.

Perangkat pembelajaran untuk memfasilitasi penalaran induktif sudah dikembangkan oleh sudria, dkk (2015) dengan hasil yang baik namun model pembelajaran problem based learning yang sekiranya cocok dengan penlaran induktif belum dikembangkan pada pokok bahasan laju reaksi, maka dalam studi ini akan mengembangkan model problem based learning dengan memodivikasi perangkat penalaran induktif yang sudah dikembangkan sebelumnya dengan materi yang sama pada topik laju reaksi. Topik laju reaksi sendiri didukung oleh data masih ditemukan fakta bahwa laju reaksi merupakan salah satu materi kimia yang dianggap sulit bagi sebagian besar siswa. Beberapa sub konsep laju reaksi mencakup konsep abstrak yang sulit divisualisasikan dan melibatkan cukup banyak persamaan matematis (Iriany, 2009). Banyak peneliti yang telah mengungkapkan miskonsepsi dan kesulitan siswa dalam memahami konsep laju reaksi. Seperti dituliskan dalam jurnal penelitian tentang laju reaksi dan hubungannya dengan konsentrasi atau tekanan oleh Cakmakci, Leach, and Domelly (2006) bahwa siswa lebih banyak menggunakan pemodelan pada level makroskopik dari pada level sub mikroskopik ataupun simbolik. Hasil penelitian lain dari Arviani (2011) menunjukkan hanyak 8,3\% siswa yang memahami teori tumbukan dan $70,8 \%$ siswa memiliki pemahaman yang salah pada konsep laju reaksi. Penelitian lain menunjukkan masih terdapat beberapa konsep laju reaksi yang mengalami miskonsepsi seperti teori tumbukan dimana orientasi yang tepat hanya terjadi antara atom-atom yang sama (Amarlita, 2010). Fakta-fakta tersebut memberikan gambaran bahwa representasi kimia pada level sub mikroskopik untuk maeri laju reaksi masih rendah.

Tujuan dari penelitian ini adalah a). untuk menghasilkan dan mendeskripsikan dokumen perangkat pembelajaran (RPP LKS, Teks Materi) model problem based learning yang konsisten dan selaras menerapkan penalaran induktif pada topik laju reaksi. b) untuk mendeskripsikan validitas (penilaian dan masukan dari ahli dan praktisi) perangkat pembelajaran dengan penalaran induktif melalui model problem based learning pada topik laju reaksi. c) Untuk mendiskripsikan signifikansi prolehan hasil belajar, proses pembelajaran dan tanggapan siswa terhadap perangkat pembelajaran melalui penalaran induktif dengan model problem based learning pada topik laju reaksi.

Oleh karena keterbatasan kesempatan, penelitian ini akan dibatasi pada pengembangan perangkat menggunakan prosedur penelitian dan pengembangan mengikuti penalaran yang dikembangkan Borg \& Gall 1989 pada (1) penelitian dan pengumpulan data (Research and Information Collation), (2) perencanaan (planning), (3) pengembangan produk pendahuluan (develop preliminary form of product), (4) uji coba pendahuluan (preliminary field testing), (5) revisi produk utama (main product revision). Gambaran tersebut selanjutnya memberikan kontribusi terhadap model pembelajaran yang dirancang agar mencakup ketiga level representasi kimia. Deengan demikian, maka penelitian ini berjudul "Pengembnagan Perangkat Pembelajaran Pendekatan Saintifik Dengan Model Problem Based Learning Melalui Penalaran Induktif Pada Topik Laju Reaksi”

\section{METODE}

Penelitian ini termasuk ke dalam model penelitian dan pengembangan $(R \& D)$ yang mengikuti prosedur yang dikembangkan oleh Borg \& Gall. Namun pada penelitian ini hanya dibatasi sampai pada tahap kelima terdiri atas: (1) penelitian dan pengumpulan data (research and information collation), (2) perencanaan (planning), (3) pengembangan produk pendahuluan (develop preliminary form of product), (4) uji coba pendahuluan (preliminary field testing), (5) revisi produk utama (main product revision).

Pada tahap penelitian dan pengembangan dilakukan melalui analisis kebutuhan melalui dua cara, yaitu studi lapangan dan studi literatur. Studi lapangan sebelumnya sudah dilakukan oleh sidria, dkk (2013) Studi tambahan dilakukan dengan penelusuran sumber-sumber yang diperlukan seperti Permendikbud Nomor 24 tahun 2016, buku-buku kimia SMA kelas XI, dan buku-buku/artikel-artikel terkait model pembelajaran sain inovatif khususnya model problem based learning, penalaran induktif, dan topik laju reaksi.

Pada tahap perencanaan dilakukan perumusan indikator pencapaian kompetensi sesuai dengan kd untuk materi laju reaksi, penajaman analisis konsep pada topik laju reaksi, penyesuaian langkah-langkah 
pembelajaran saintifik $5 \mathrm{~m}$ dalam model problem based learning, sinergisitas model problem based learning yang mengakomodasi langkah-langkah pendekatan saintifik $5 \mathrm{~m}$ pada perangkat pembelajaran (rpp, lks, teks materi pelajaran dan instrumen), rancangan validasi perangkat pembelajaran. Pada tahap pembuatan produk

Pada tahap pembuatan produk perangkat pembelajaran akan disusun sesuai dengan rancangan yang telah dibuat. Pembuatan perangkat pembelajaran dilakukan bertahap melalui dari RPP dan instrumen penilaian, LKS, dan terakhir teks materi pelajaran. Proses penelitian pada tahap ini disertai dengan melakukan validasi rancangan produk oleh pakar yang ahli dalam bidangnya, yaitu satu orang dosen Pendidikan kimia dan dua orang guru kimia.

Pada tahap uji coba pendahuluan dilakukan di SMA Negeri 4 Singaraja dengan melibatkan kelas XI yang dilakukan ditiga kelas yakni XI MIPA 3, XI MIPA 4 dan XI MIPA 6. Keterlaksaan proses pembelajaran sesuai dengan mandat kurikulum 2013 (pendekatan saintifik) dengan mengacu pada rubrik aktivitas $5 \mathrm{M}$ yang dinilai pada masing-masing siswa, penilaian terhadap dokumen LKS, hasil tes belajar siswa, serta respon siswa. Pada tahap uji coba ini dilakukan penelitian Pre-experimental dengan rancangan penelitian one group pretest-posttest. Adapun rancangan eksperimen one grup pretest-posttest desing pada gambar 3.2

\begin{tabular}{|c|c|c|}
\hline Pretest & Perlakuan & Posttest \\
\hline $\mathbf{O}_{1}$ & $\mathbf{X}$ & $\mathbf{O}_{2}$ \\
\hline
\end{tabular}

Gambar 3.2 Pre-eksperimen One Grup Pretest-Posttest Design

Pada tahap revisi produk utama dilakukan berdasarkan hasil masukan dari angket tanggapan (respon) siswa dan masukan dari guru terhadap pelaksanaan pembelajaran.

Subyek dan Obyek Penelitian dan Pengembangan Pada tahap penelitian dan pengumpulan data, penajaman analisis kebutuhan dilakukan melalui studi literatur. Subyek pada studi literatur adalah Permendikbud Nomor 24 tahun 2016, dan artikel/jurnal nasional maupun internasional terkait penalaran induktif dan model-model pembelajaran sains inovatif khususnya model problem based learning. Obyek pada studi literatur berupa kompetensi bahan kajian kimia terkait konsep laju reaksi dan penalaran induktif serta pentingnya variasi penggunaan model pembelajaran. Pada tahap perencanaan Subyek pada tahapan ini meliputi Permendikbud Nomor 103 Tahun 2014 dan Permendikbud Nomor 24 Tahun 2016, pendekatan saintifik dan model problem based learning, serta perangkat pembelajaran. Obyek dari tahapan ini adalah komponen dalam model dasar saintifik dan model problem based learning, keselarasan perangkat pembelajaran dengan penalaran induktif dengan model pembelajaran problem based leraning, kompetensi dasar pada Permendikbud Nomor 24 Tahun 2016, dan rancangan produk perangkat pembelajaran sesuai karakteristik masing-masing. Pada tahap pembuatan dan pengembangan produk Subyek dari tahapan ini adalah produk perangkat pembelajaran dan obyeknya adalah konsistensi produk perangkat pembelajaran model pembelajaran problem based learning dengan penalaran deduktif dan serta keselarasan semua perangkat pembelajaran. Pada tahap uji coba pendahuluan, subyek penelitian adalah 9 orang siswa dan 98 siswa kelas XI MIPA SMA Negeri 4 Singaraja, sedangkan obyek penelitiannya adalah tingkat keterbacaan, penilaian terhadap dokumen LKS, hasil tes belajar siswa, respon siswa dan masukan terhadap perangkat pembelajaran.

Tekni analisis data pada tahap uji coba pendahulu yakni berdasarkan data hasil belajar menggunakan analisis inferensial, sedangkan analisis data aktivitas belajar siswa dan tanggapan siswa terhadap pelaksanaan pembelajaran menggunakan analisis deskriptif. Uji analisis ifrensial dilakukan untuk menguji keefektivitas dengan menggunakan statistik parametrik dan/atau nonparametrik. Uji normalitas data dilakukan terhadap skor pretespostes. Uji normalitas sebaran data menggunakan statistik Kolmogorof smirnov. Data berdistribusi normal apabila angka signifikansi yang dihasilkan lebih dari 0,05. Jika data berdistribusi normal, maka uji keefektivitas dilakukan dengan menggunakan statistik parametrik, yaitu paired sample t-test (uji-t sampel berpasangan). Jika data tidak terdistribusi normal, maka uji hipotesis dilakukan dengan statistik nonparametrik, yaitu uji Wilcoxon. Perhitungan semua uji statistik yang digunakan dalam penelitian ini dilakukan dengan bantuan program SPSS 16 for WindowS pada taraf signifikansi 5\%.

Hasil dari posttes siswa yang diperoleh digunakan untuk menguji instrumen penilaian (tes hasil belajar) yang dikembangkan. Pengujian tes hasil belajar meliputi kevalidan, reabilitas, tingkat kesukaran dan daya beda tes. 


\section{HASIL DAN PEMBAHASAN}

\section{Hasil Penelitian dan Pengumpulan Data (Analisis Kebutuhan)}

Hasil analisi kebutuhan ini dilakukan studi lapangan dan studi literatur. Studi lapangan berupa analisi dokumen perangkat pembelajaran yang telah dilakukan sebelumnya oleh sudria, dkk (2013) menjelaskan bahwa LKS dan teks materi pelajaran sebagai sumber belajar dan pembelajaran merupakan perangkat pembelajaran yang paling mendekati representatif urutan langkah-langkah kegiatan belajar dan penalaran (induktif/deduktif). Hasil studi ini mendukung bahwa belum tersedianya perangkat pembelajaran sains inovatif serta mengakomodasikan keterampilan proses sains. Untuk menindaklanjuti hasil lapangan, pengembangan perangkat pembelajaran baru sampai menghasilkan perangkat dengan model dasar saintifik yaitu guided inquiry yang dilakukan oleh sudria (2015) pada topik laju reaksi. Sementara kurikulum 2013 merekomendasikan menggunakan variasi model-model pembelajaran inovatif yang mendukung pencapaian tujuan pembelajaran. sedangkan pada studi literatur Permendikbud Nomor 24 tahun 2016 : pembelajaran kurikulum 2013 menggunakan pendekatan saintifik; belajar melalui penemuan secara ilmiah. Perangkat pembelajaran menagkomodasi model pembelajaran yakni kerangka konseptual yang digunakan sebagai pedoman dalam melaksanakan pembelajaran (Joyce \& Weil, 1980). Tidak ada satupun model pembelajaran yang sesuai/cocok diterapkan pada semua situasi instruksional pembelajaran Pembelajaran yang efektif membutuhkan penggunaan variasi model (Horenstein \& Seabert, 2005). Model pembelajaran problem based learning merupakan model pembelajaran berdasarkan masalah yang didasari banyaknya permasalahan yang membutuhkan penyelidikan autentik yakni penyelidikan yang membutuhkan penyelesaian masalah dari permasalahan nyata (Trianto, 2012). Model problem based learning membantu siswa mengembangkan keterampilan berpikir kritis dan keterampilan berbasis masalah dan memecahkan masalah (Arends, 2008). Efektivitas model problem based learning dapat ditemukan pada susdarwati, dkk (2016), Rina Rahayu, dkk (2015), dan Nayank, dkk (2018).

\section{Hasil Perencanaan}

Hasil yang diperoleh yakni perumusan indikator pencapaian kompetensi sesuia dengan KD pada silabus kimia kurikulum 2013 revisi tahun 2016. Adapun perubahan KD meliputi rumusan KD 3.6, 3.7 dan 4.6, 4.7.

penajaman analisis pengetahuan dan konsepsi topik laju reaksi yakni Pada unit 1 konsep yang dibangun yakni mendefinisikan laju reaksi, laju reaksi rata-rata, laju reaksi sesaat, pengaruh konsentrasi terhadap laju reaksi, pengaruh suhu terhadap laju reaksi, pengaruh luas permukaan terhadap laju reaksi, pengaruh katalis terhadap laju reaksi. Pada unit 2 konsep yang dibangun terdiri atas orde reaksi, hukum laju, teori tumbukan, energi aktivasi, tumbukan efektif, pengaruh katalis. Pada unit 3 konsep yang harus dibangun yakni Teknologi/aktivitas pengaruh laju reaksi. Ketiga unit yang dibagi masing-masing memiliki jenis konsep dan dengan konsep prasyarat. jenis konsep terdiri atas konkrit (K) dan berdasarkan prinsi (BP), Ciri abstrak contoh konkrit(Cak), sedangkan konsep prasyarat terdiri atas unit 1, Reaksi kimia (K), reaktan $(\mathrm{K})$, produk $(\mathrm{K})$, laju $(\mathrm{K})$, molaritas (BP), stoikiometri (BP), kemiringan (gradien) kurva di suatu titik (BP), luas permukaan, dan program garis lurus (BP), unit 2 : Laju reaksi sesaat (BP); unit 3 : pengaruh suhu dan konsentrasi terhadap laju reaksi(K), Pengaruh suhu,konsentrasi, luas permukaan, dan/atau katalis terhadap laju reaksi $(\mathrm{K})$

Penyelarasan langkah-langkah pembelajaran saintifik 5M dengan model problem based learning,

sinergitas model problem based learning yang mengakomodasikan langkah-langkah pendekatan saintifik 5M pada perangkat pembelajaran (RPP, LKS, Teks materi

Rancangan Validasi Perangkat Pembelajaran Pada tahapan ini juga dibuat rancangan lembar validasi dan lembar uji keterbacaan. Lembar validasi dan lembar uji keterbacaan yang digunakan adalah yang sudah dikembang oleh Sudria, Kartowasono, Frieda, \& Sya'ban (2013) yang telah dimodivikasi. Penilian RPP berdasarkan aspek-aspek indikator yang dinilai anatara lain kelengkapan lampiran sesuai dengan rancangan dalam RPP, kejelasan perumusan tujuan pembelajaran, perumusan indikator, pengorganisasian materi ajar, rancangan strategi ajar, kejelasan skenario pembelajaran dalam aktivitas pembelajaran. Sedangkan untuk LKS aspek yan dinilai anatara lain organisasi penulisan, isi, organisasi kegiatan pembelajaran, untuk Teks materi dan instrumen penilian aspek yang dinilai antara lain organisasi penulisan, isi, dan organisasi. Lembar uji keterbacaan yang dilakukan oleh beberapa siswa memiliki indikator setiap objek yang akan dinilai antara lain LKS, Teks materi dan teks materi.

\section{Hasil Pembuatan Produk}


Produk yang dihasilkan yakni perangkat pembelajaran melalui penalaran induktif dengan dengan model pembelajaran problem based learning pada topik laju reaksi. Perangkat pembelajaran dari pembuatan produk yang dibuat meliputi rencana pelaksanaan pembelajaran (RPP), lembar kerja siswa (LKS), teks materi pelajaran, dan instrumen penilian (kisi-kisi asesmen, tes hasil belajar). Perangkat pembelajaran yang dihasilkan mengikuti pendekatan saintifik (5M) melalui penalaran induktif dengan model problem based learning. Struktur setiap perangkat pembelajaran konsisten mengikuti tahapan 5M (mengamati, menanya, mengumpulkan data, mengasosiasi dan mengkomunikasikan) melalui penalaran induktif dengan model pembelajaran problem based learning yang diamanatkan oleh kurikulum (2013).

\section{a. Rencana Pelaksanaan Pembelajaran (RPP)}

Rencana Pelaksanaan Pembelajaran (RPP) yang dihasilkan dibatasi pada topik laju reaksi dan dibuat dengan mengakomodasi kompetensi inti dan kompetensi dasar sesuai dengan kurikulum 2013 dan Permendikbud nomor 24 tahun 2016 dengan pendekatan saintifik (5M). Konsep-konsep yang telah dijabarkan untuk pencapain indikator-indikator dikelompokkan kedalam tiga unit kegiatan pembelajaran dimana disesuaikan dengan alur penalaran induktif. Ketiga unit pembelajaran tersebut adalah (1) unit pembelajaran pertama tentang definisi laju reaksi; (2) unit pembelajarn kedua tentang faktor-faktor laju reaksi dan hubungan faktorfaktor tehadap teori tumbukan; (3) unit pembelajaran ketiga tentang orde reaksi dan hukum laju reaksi. Alokasi waktu keseluruhan untuk pembelajaran di kelas sebanyak $12 \times 45$ menit yang telah meliputi kegiatan remedial, dan postest. Alokasi waktu untuk masing-masing unit pembelajaran (I-IV) adalah $2 \times 45$ dan $2 \times 45$ menit untuk pretes postes. Postes dilaksanakan setelah semua unit pembelajaran untuk pokok bahasan laju reaksi terlaksana atau pada pertemuan kelima sedangkan kegiatan remdial dilaksanakan diakhir dari kegiatan post test.

\section{b. Lembar Kerja Siswa (LKS)}

LKS yang dikembangkan konsisten mengikuti pedekatan saintifik (5M) kurikulum 2013 dan sesuai dengan model pembelajaran problem based learning. Lembar kerja siswa yang dibuat dilengkapi dengan media berupa data, gambar, dan tabel. Secara langsung siswa diajak belajar (menemukan masalahmasalah dan memecahkan masalah dari suatu fenomena yng terdapat pada teks pengantar di LKS). Kegiatan pembelajaran yang telah dijabarkan untuk pencapain indikator-indikator dikelompokkan kedalam empat kelompok LKS dimana disesuaikan dengan alur penalaran induktif dengan model problem based learning. Keempat unit tersebut adalah (1) unit LKS pertama tentang definisi laju reaksi; (2) unit LKS kedua tentang faktor-faktor yang mempengaruhi laju reaksi; (3) unit LKS ketiga tentang hubungan faktor-faktor tehadap teori tumbukan; (4) unit LKS keempat tentang orde reaksi dan hukum laju reaksi. Pengaturan kegiatan pembelajaran dalam LKS disesuaikan dengan alokasi waktu pada silabus. Untuk mengefektifkan waktu pembelajaran dan mengakomodasi siswa dapat belajar secara individu maka berdasarkan pendekatan saintifik (5M) pada fase mengamati, menanya dan mengumpulkan data dilakukan dirumah sebagai tugas pra pembelajaran. Setiap akhir kegiatan LKS terdapat pengayaan sebagai tugas yang akan dikerjakan oleh siswa dirumah dengan tujuan agar tercapainya suatu pembelajaran apabila terjadinya kekurangna waktu pada proses pembelajaran.

\section{c. Teks materi pelajaran}

Teks materi pelajaran pada topik laju reaksi dikembangkan sebagai salah satu sumber informsi materi laju reaksi yang dikondisikan sesuai konsisten dengan pendekatan saintifik melalui penalaran induktif. Penyajian materi pada teks materi pelajaran mengikuti alur penalaran induktif yang berangkat dari pengenalan fenomena awal (Khusus) kemudian ditarik kesimpulan yang berupa umum. Teks materi yang telah dibuat terdiri atas materi-materi yang mendukung pencapain kompetensi dasar dari topik laju reaksi. Materi yang terkndung dalam teks materi pelajaran meliputi definisi laju reaksi, faktor-faktor laju reaksi, hubungan laju reaksi dengan teori tumbukan, orde raksi, dan hukum laju.

\section{d. Instrumen Penilaian}

Instrumen penilaian yang dibuat meliputi multibentuk asesmen untuk menilai sasaran secara komprehensip mencakup aspek kognitif, psikomotorik, san afektif). Relevansi asesmen terhadap indikator kopetensi dan aspek keterampilan proses sains diupayakan melalui penyusunan kisi-kisi multibentuk asesmen dan rubrik penilaiannya (Lampiran 07). Contoh penggalan rancangan (kisi-kisi) multibentuk asesmen yang dikembangkan dalam $\mathrm{R} \& \mathrm{D}$ ini disajikan dalam Tabel 4.4. Instrumen penilaian disajikan dengan sasaran dan bentuk asesmen. Sasaran penilaian meliputi aspek kognitif, psikomotor, dan afektif. Bentuk/ metode penilaian menggunakan bentuk pilihan ganda, essay, dan perform/kinerja (Stiggin, 1989). Sasaran kognitif (kognitif proses sains) diukur melalui tes yakni pilihan ganda dan tes uraian dengan pertimbangan kepraktisan dan ketercakupan sasaran penilaian. Sasaran kognitif keterampilan proses sains mengakomodasi aspek keterampilan proses sains. Sementara sasaran psikomotor dan afektif yang berupa unjuk kerja (performan) termasuk produk laporan praktikum yang terbatas pada performan kelompok diukur dengan lembar observasi atau penilaian yang dilengkapi dengan rubrik penilaian 
(selanjutnya hanya disebut rubrik penilaian). Untuk sasaran afektif yang berkaitan dengan perilaku kepercayaan terhadap Tuhan (KI-1) dan sosial (KI-2) diungkap melalui lembar pengamatan yang disertai rubrik penilaian performan dan/ atau melalui angket

\section{Hasil Validasi Produk dan Uji Keterbacaan}

Validasi perangkat pembelajaran pada penelitian ini dilakukan secara bersamaan dengan uji coba pendahuluan, hal ini disebabkan karena pertimbangan waktu dengan jaminan bahwa perangkat ini telah diperiksa dan divalidasi oleh pembimbing yang sudah expert dibidang ini. Pertimbangan yang lain juga karena penelitian ini hanya memodivikasi perangkat pembelajaran yang sebelumnya sudah dikembangkan kedalam model problem based learning untuk topik yang sama yaitu topik laju reaksi. Sehingga dari segi materi tidak terdapat banyak perubahan, namun masih tetap harus dilakukan validasi oleh ahli dan praktisi. Validasi produk ini dilakukan oleh 1 orang ahli (ahli isi sekaligus ahli pedagogi) dan 2 orang praktisi (guru Kimia SMA). Validasi perangkat pembelajaran ini mencakup organisasi penulisan, isi, dan organisasi perangkat pembelajaran. Kelayakan yang dilakukan uji coba pendahulan dari hasil validasi oleh pembimbing diperkuat oleh hasil validasi dari ahli dan praktisi.

\section{a. Validasi Produk}

Validasi perangkat pembelajaran dilakukan oleh satu orang dosen $\left(D_{1}\right)$ dan dua orang guru kimia SMA selaku praktisi ( $\mathrm{G}_{1}$ dan $\mathrm{G}_{2}$ ). Validasi perangkat pembelajaran mencakup umum, isi dan organisasi perangkat pembelajaran. Secara umum, penilaian dari ahli dan praktisi terhadap aspek organisasi penulisan, isi, dan organisasi perangkat pembelajaran saintifik melalui penalaran induktif dengan model pembelajaran problem based learning pada topik laju reaksi adalah baik (B) dan sangat baik (SB). Dari ketiga validator yang memvalidasi perangkat pembelajaran, satu validator, yakni dosen selaku ahli isi dan pedagogi (D1) memberikan nilai sangat baik (SB) pada seluruh butir penilaian perangkat pembelajaran $(100 \%)$. Sedangkan dua validator sebagai ahli praktisi pertama $\left(\mathrm{G}_{1}\right.$ dan $\mathrm{G}_{2}$ ) umumnya memberikan penilaian baik (B) dan sangat baik (SB). Validator ahli praktisi pertama ( $\mathrm{G}_{1}$ ) berturut-turut memberikan nilai sebesar $22 \%$ dan $78 \%$ terhadap perangkat pembelajaran yang dikembangkan sedangkan validator ahli praktisi kedua $\left(\mathrm{G}_{2}\right)$ berturut-turut memberikan nilai sebesar $61 \%$ baik dan 39\% sangat baik.

\section{b. Uji Keterbacaan}

Hasil uji keterbacaan terhadap perangkat pembelajaran yakni lembar kerja siswa (LKS), teks materi pelajaran dan tes hasil belajar. Uji keterbacaan ini dilakukan oleh 9 orang siswa kelas XI MIPA. Uji keterbacaan bertujuan untuk mengetahui gambaran secara umum mengenai tingkat keterbacaan siswa terhadap perangkat pembelajaran yang telah dibuat. Data hasil uji keterbacaan perangkat pembelajaran saintifik melalui penalaran induktif dengan model pembelajaran problem based learning pada topik laju reaksi menunjukkan bahwa tingkat keterbacaan LKS, teks materi pelajaran, dan tes hasil belajar berada pada level kurang, baik dan sangat baik. Semua siswa (berjumlah 9 orang) memberikan penilaian baik dan sangat baik terhadap semua butir aspek. Rata-rata tingkat uji keterbacaan dari LKS adalah 11,11\% kurang, 68,51 baik dan 20,37\% sangat baik. Rata-rata tingkat uji keterbacaan teks materi adalah 66,67\% baik dan 33,33\% sangat baik. Sementara itu rata-rata uji keterbacaan dari tes hasil belajar adalah 4,76\% kurang, $46,03 \%$ baik dan $49,20 \%$ sangat baik.

\section{Hasil Uji Pendahuluan dan Revisi Produk Utama}

Hasil uji coba pendahuluan yang diperoleh data dari hasil belajar pretest(sebelum diberi perlakuan) dan posttest(setelah diberi perlakuan) untuk menilai keterampilan proses sains siswa yang juga mengindikasikan keefektifan proses pembelajaran dengan menggunakan perangkat pembelajaran saintifik yang dikembangkan, tanggapan siswa terhadap pelaksanaan pembelajaran, aktivitas belajar siswa. Berdasarkan hasil pretes dan pos tes siswa data yang dikumpulkan, diperoleh skor pretes yang dicapai siswa berkisar antara 7,00 sampai dengan 45,00 sedangkan skor postes yang dicapai siswa berkisar antara 36,00 sampai dengan 95,00.

Hasil dari posttest siswa pada pada tahap penelitian ini juga digunakan untuk menguji kevalidan, reliabilitas, tingkat kesukaran dan daya beda tes hasil belajar yang dikembangkan. Hasil uji kevalidan menunjukan bahwa 25 butir soal pilihan ganda dan 5 soal uraian dinyatakan valid. Hasil uji realibilitas menunjukan bahwa 25 soal pilihan ganda menunjukkan reliabilitas 0,68 yang berarti tinggi, sedangkan pada 5 butir soal uraian menunjukkan reliabiltas 0,90 yang berarti sangat tinggi. Hasil uji tingkat kesukaran pada 25 butir soal pilihan ganda menunjukkan 12\% soal mudah dan 88\% soal sedang, sedangkan pada 5 butir soal uraian menunjukkan 55,5\% mudah dan 44,4\% sedang. Hasil uji daya beda pada 25 butir soal pilihan ganda menunjukkan 2 soal memiliki daya beda baik dan 23 soal memiliki daya beda sedang, sedangkan uji daya beda pada 5 butir soal uraian menunjukkan 2 soal memiliki daya beda baik dan 7 soal memiliki daya beda sedang.

\section{Hasil Belajar Siswa}


Hasil belajar pretest(sebelum diberi perlakuan) dan posttest(setelah diberi perlakuan) untuk menilai keterampilan proses sains siswa yang juga mengindikasikan keefektifan proses pembelajaran dengan menggunakan perangkat pembelajaran saintifik yang dikembangkan. Berdasarkan data yang dikumpulkan, diperoleh skor pretes yang dicapai siswa berkisar antara 7,00 sampai dengan 45,00 sedangkan skor postes yang dicapai siswa berkisar antara 36,00 sampai dengan 95,00. Lebih lanjut, dilakukan uji normalitas terhadap skor pretes dan postes siswa baik secara keseluruhan maupun pada setiap indikator laju reaksi. Uji normalitas skor pretes dan postes menggunakan statistik KolmogorovSmimov. Data berdistribusi normal jika nilai signifikansi lebih besar dari 0,05

Tabel 1. Ringkasan Hasil Uji Normalitas Pretest dan Posttest Indikator KI-3

\begin{tabular}{clcccc}
\hline Indikator & Data & \multicolumn{3}{c}{ Kolmogorov-Smimov } & Distribusi \\
\cline { 2 - 4 } KI-3 & & Statistic & Df & Sig. & \\
\hline Pengertian & Pretes & 0.147 & 98 & 0.000 & Tidak Normal \\
laju & Postes & 0.092 & 98 & 0.042 & Tidak Normal \\
Faktor-faktor & Pretes & 0.075 & 98 & 0.198 & Normal \\
laju reaksi & Postes & 0.093 & 98 & 0.038 & Tidak Normal \\
Hubungan & Pretes & 0.223 & 98 & 0.000 & Tidak Normal \\
faktor & Postes & 0.195 & 98 & 0.000 & Tidak Normal \\
terhadap teori & & & & \\
tumbukan & & & & \\
Cara-cara & Pretes & 0.351 & 98 & 0.000 & Tidak Normal \\
penyimpanan & Postes & 0.294 & 98 & 0.000 & Tidak Normal \\
bahan & & & & & \\
Orde Reaksi & Pretes & 0.308 & 98 & 0.000 & Tidak Normal \\
Hukum laju & Postes & 0.264 & 98 & 0.000 & Tidak Normal \\
Pretes & 0.264 & 98 & 0.000 & Tidak Normal \\
Merancang & Postes & 0.283 & 98 & 0.000 & Tidak Normal \\
percobaan & Pretes & 0.454 & 98 & 0.000 & Tidak Normal \\
Keseluruhan & Postes & 0.164 & 98 & 0.000 & Tidak Normal \\
Indikator & Pretes & 0.056 & 98 & 0.200 & Normal \\
\hline
\end{tabular}

Tabel 2. Ringkasan Taraf Signifikan Hasil Per Indikator dan Keseluruhan.

\begin{tabular}{|c|c|c|c|c|c|c|c|c|}
\hline No & $\begin{array}{c}\text { Indikator KI } \\
3\end{array}$ & $\begin{array}{l}\text { Rata- } \\
\text { rata } \\
\text { Pre }\end{array}$ & $\begin{array}{l}\text { Rata- } \\
\text { rata } \\
\text { Pos }\end{array}$ & $\begin{array}{c}\text { Dis } \\
\text { t. }\end{array}$ & $\begin{array}{c}\text { Uji } \\
\text { Hipotesis }\end{array}$ & $\begin{array}{l}\mathrm{t} \text { atau } \mathrm{z} \\
\text { hitung }\end{array}$ & $\begin{array}{l}\text { Signifikan } \\
\text { (2-tailed) }\end{array}$ & NGS \\
\hline 1 & $\begin{array}{l}\text { Pengertian } \\
\text { Laju Reaksi }\end{array}$ & 6,03 & 12,24 & TN & Wilcoxon & 3.35 & $\begin{array}{c}0.0004 \\
\text { (Signifikan) }\end{array}$ & $\begin{array}{c}0,43 \\
\text { (sedang) }\end{array}$ \\
\hline 2 & $\begin{array}{l}\text { Faktor-Faktor } \\
\text { Laju Reaksi }\end{array}$ & 10,13 & 23,44 & $\mathrm{TN}$ & Wilcoxon & 3.35 & $\begin{array}{c}0.0004 \\
\text { (Signifikan) }\end{array}$ & $\begin{array}{c}0,52 \\
\text { (sedang) }\end{array}$ \\
\hline 3 & $\begin{array}{l}\text { Teori } \\
\text { Tumbukan }\end{array}$ & 2,939 & 9,714 & TN & Wilcoxon & 3.35 & $\begin{array}{c}0.0004 \\
\text { (Signifikan) }\end{array}$ & $\begin{array}{c}0,61 \\
\text { (sedang) }\end{array}$ \\
\hline 4 & $\begin{array}{l}\text { Cara-cara } \\
\text { Penyimpanan } \\
\text { Bahan }\end{array}$ & 0,918 & 0,959 & $\mathrm{TN}$ & Wilcoxon & 3.35 & $\begin{array}{c}0.0004 \\
\text { (Signifikan) }\end{array}$ & $\begin{array}{c}0,30 \\
\text { (sedang) }\end{array}$ \\
\hline 5 & Orde Reaksi & 1,183 & 2,489 & $\mathrm{TN}$ & Wilcoxon & 3.35 & $\begin{array}{c}0.0004 \\
\text { (Signifikan) }\end{array}$ & $\begin{array}{c}0,41 \\
\text { (sedang) }\end{array}$ \\
\hline 6 & Hukum Laju & 1,561 & 10,54 & TN & Wilcoxon & 3.35 & $\begin{array}{c}0.0004 \\
\text { (Signifikan) }\end{array}$ & $\begin{array}{c}0,72 \\
\text { (tinggi) }\end{array}$ \\
\hline 7 & $\begin{array}{l}\text { Merancang } \\
\text { Percobaan }\end{array}$ & 0,403 & 5,724 & $\mathrm{TN}$ & Wilcoxon & 3.35 & $\begin{array}{c}0.0004 \\
\text { (Signifikan) }\end{array}$ & $\begin{array}{c}0,55 \\
\text { (sedang) }\end{array}$ \\
\hline 8 & Keseluruhan & 23,27 & 65,18 & $\mathrm{~N}$ & t-test & 35.15 & $\begin{array}{c}0.000 \\
\text { (Signifikan) }\end{array}$ & $\begin{array}{c}0,5 \\
\text { (sedang) }\end{array}$ \\
\hline
\end{tabular}

Berdasarkan hasil sampel berpasangan untuk data yang berdistribusi normal dan statistik nonparametrik Wilcoxon, diperoleh semua indikator dan keseluruhan memiliki $p$-value (significance) $<0,05$ dengan demikian hasil belajar berdasarkan indikator yang diperolah menunjukkan belajar yang signifikan melalui pembelajaran dengan model pembelajaran problem based learning. Data pada tabel menunjukkan bahwa 
rerata skor pretest tiap indikator berkisar antara 0,40 sampai 10,13 dengan rerata keseluruhan sebesar 23,27. Jika dikonversi maka rerata keseluruhan skor pretest termasuk kategori sangat kurang. Setelah mengikuti pembelajaran dengan menggunakan perangkat pembelajaran saintifik, siswa memperoleh rerata skor postest tiap indikator berkisar antara 0,95 sampai 23,44 dengan rerata keseluruhan sebesar 65,5. Selain dilakukan analisis inferensial, hasil belajar siswa dianalisis secara deskriptif yang meliputi rerata skor pretes, postes, dan NGS. Rerata skor pretes, postes, dan NGS secara keseluruhan masingmasing indikator dan tanggapan siswa dideskriptifkan berdasarkan angket tanggapan yang telah diisi oleh siswa sendiri setelah proses pembelajaran selasai diterapkan. Berdasarkan profil perolehan belajar proses sains di atas, terlihat bahwa indikator KI 3 siswa menunjukkan perolehan belajar yang tinggi berada pada pembelajaran dengan indikator laju reaksi adalah hukum laju. Dari pembelajaran yang berlangsung siswa lebih banyak belajar berdasarkan data-data yang mereka peroleh baik berdasarkan hasil data praktikum sebelumnya yang dilakukan pada pembelajaran faktor-faktor yang mempengaruhi laju reaksi, dan orde reaksi. Sehingga ketika penerapan rumus pada hukum laju siswa cendrung lebih mudah memahami data yang mereka peroleh untuk diterapkan pada penentuan hukum laju. Dari hasil ini juga dapat dilihat bahwa indikator dari KI 3 menunjukkan perolehan belajar yang cukup signifikan melalui perangkat pembelajaran saintifik yang dikembangkan. Hal ini berarti perangkat pembelajaran yang digunakan memberikan dampak yang efektif bagi pelaksanaan pembelajaran.

\section{Proses Kinerja $5 \mathrm{M}$}

Proses kinerja aktivitas $5 \mathrm{M}$ dilihat dari penilian dokumen LKS yang dihasilkan dari hasil kerja siswa berjumlah 106 orang menunjukkan kecendrungan rata-rata aktivitas $5 \mathrm{M}$ siswa mengalami peningkatan, seperti yang ditunjukkan pada grafik berikut gambar 2. Dari grafik diatas menunjukkan bahawa rata-rata pada masing-masing aspek aktivitas 5M yang dinilai dari hasil pengerjan LKS untuk setiap pertemuan. Rata-rata paling tinggi terdapat pada pertemuan ketiga yaitu pada fase mengkomunikasikan. Pada pertemuan ini, siswa mempelajari materi tentang hubungan faktor-faktor dengan teori tumbukan. Siswa yang belajar dengan penalaran induktif cenderung lebih berperan aktif pada fase ini contoh-contoh penerapan fenomena secara nyata dipahami dengan baik. Dari hasil ini dapat disimpulkan bahwa belajar dengan pendekatan saintifik bila dilakukan dengan pembiasaan akan menunjukkan peningkatan.

\section{Respon Siswa Terhadap Pelaksanaan Pembelajaran}

Data respon(tanggapan siswa) siswa terhadap pembelajaran kimia dengan menerapkan perangkap pembelajaran dengan penalaran induktif dalam penelitian ini diukur dengan angket tertutup yang disajikan secara ringkas pada Tabel 3. Berdasarkan data angket yang telah diisi siswa terhadap implementasi perangkat pembelajaran dengan pola induktif, dari jawaban siswa sebagian besar menjawab sangat setuju dan setuju untuk setiap butir pernyataan. Angket yang digunakan berisi 32 pernyataan yang digolongkan menjadi 4 aspek yaitu ; 1) Lembar Kerja Siswa (LKS), 2) Keterampilan Proses Sains Siswa (Induktif), 3) Manfaat Bagi Pemahaman Konsep Siswa, dan 4) Pengalaman Bagi Siswa. Skor tertinggi ideal dalam penilaian angket ini adalah 5 dan skor terendah ideal adalah 1. Data pada tabel 4.4 menunjukkan bahwa tanggapan siswa terhadap pelaksanaan pembelajaran menggunakan perangkat pembelajaran dengan pola induktif jika dilihat dari masing-masing aspek didapatkan bahwa tanggapan siswa terhadap aspek LKS adalah baik dengan rata-rata nilai 3,64, aspek keterampilan proses sains siswa adalah baik dengan rata-rata nilai 3,59, aspek manfaat bagi pemahaman konsep siswa adalah baik dengan rata-rata nilai 3,65, dan aspek pengalaman bagi siswa adalah baik dengan rata-rata nilai 3,70. Hal tersebut mengindikasikan bahwa uji coba utama perangkat pembelajaran dengan penalaran induktif mendapat respon yang baik dari siswa.. 


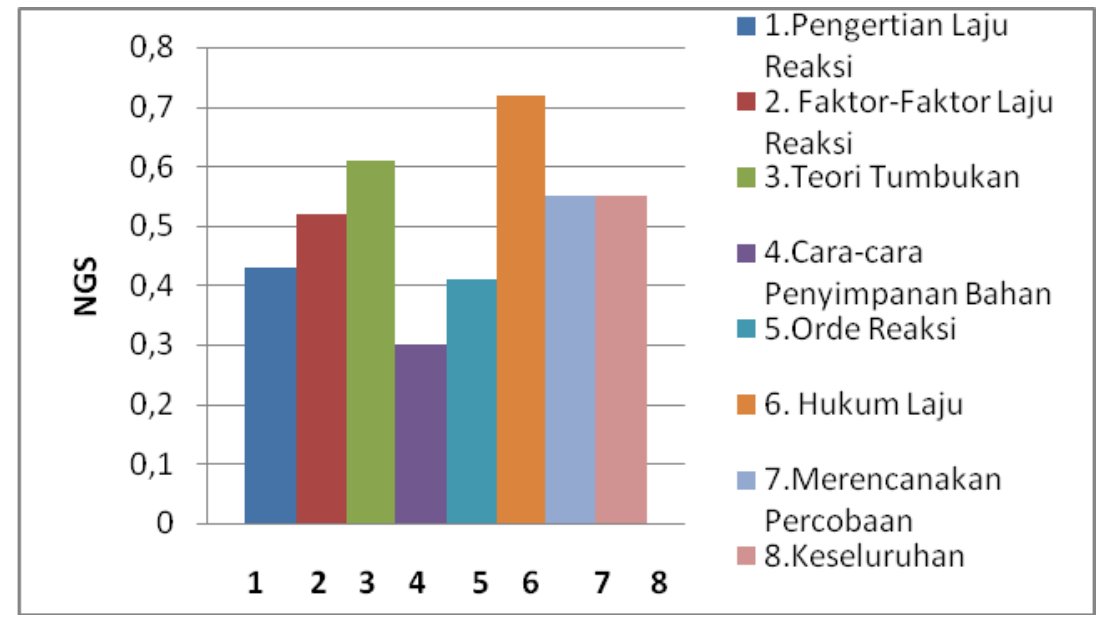

Gambar 1. Profil Perolehan Hasil Belajar Siswa

Untuk Masing-Masing dan Keseluruhan Indikator

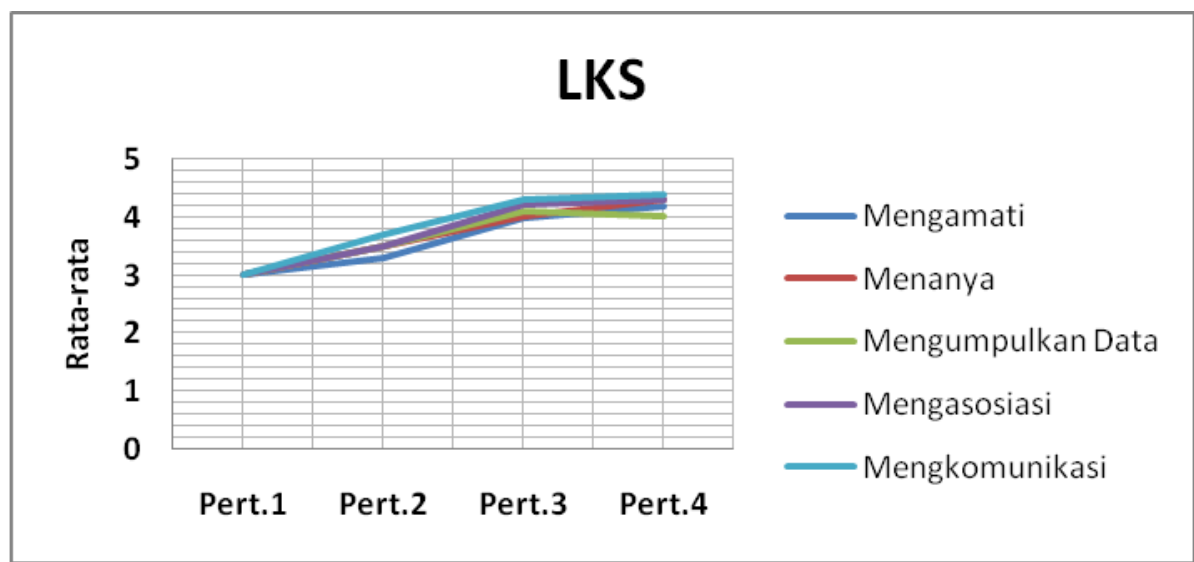

Gambar 2. Grafik Rata-Rata Aktivitas 5M

Berdasarkan Penilian Dokumen LKS

Tabel 3. Ringkasan Data Respon Siswa pada Tiap Aspek Penilaian

\begin{tabular}{llcl}
\hline No & \multicolumn{1}{c}{ Aspek } & Nilai & Kriteria \\
\hline 1 & Lembar kerja siswa (LKS) & 3,64 & Baik \\
2 & Keterampilan proses sains siswa (Induktif) & 3,59 & Baik \\
3 & Manfaat bagi pemahaman konsep & 3,65 & Baik \\
4 & Pengalaman bagi siswa & 3,70 & Baik \\
\hline
\end{tabular}

\section{PEMBAHASAN}

Hasil penelitian ini menunjukkan bahwa R \& D mampu mengantarkan keberhasilan pengembangan suatu produk saintifik dari perangkat pembelajaran melalui penalaran induktif dengan model pembelajaran problem based learning yang konsisten dan selaras. Implementasi produk yang dihasilkan mampu mengantarkan perolehan hasil belajar yang signifikan berdasarkan nilai NGS yaitu 0,55 dengan kategori sedang dengan rata-rata postest adalah 65,18 kemampuan aktivitas belajar siswa 5M yang cendrung meningkat berdasarkan penugasan LKS, dan mendapatkan tanggapan siswa yang tergolong baik. Keberhasilan ini dipengaruhi oleh konsisten mengikuti langkah-langkah penelitian dan pengembangan (R\&D) berdasarkan prosedur Borg \& Gall (1989), dengan struktur pembelajaran menggunakan pendekatan saintifik melalui penalaran induktif dengan model pembelajaran problem based 
learning. Disamping itu perangkat pembelajaran yang dikembangkan (RPP, LKS, Teks Materi dan Instrumen Penilian) setiap unit pembelajaran menggunkan penyelarasan pendekatan saintifik $5 \mathrm{M}$.

Keberhasilan produk diawali dengan menganalisis kebutuhan yang didukung. Hasil analisis kebutuhan mejadi landasan dalam pengembangan perangkat pembelajaran dengan model problem based learning. Hasil studi lapangan membuktikan bahwa masih belum tersedianya perangkat pembelajaran saintifik dengan menggunakan alur penalaran yang konsisten dan mengakomodasi model pembelajaran inovatif khusunya pada topik laju reaksi. Hasil studi literatur juga menekankan dalam pembelajaran sains dikenal dua penalaran yakni induktif dan deduktif. Model problem based learning merupakan salah satu model pembelajaran yang direkomendasikan dalam kurikulum 2013 sebagai salah satu model pembelajaran yang inovatif. Efektivitas pembelajaran dengan model problem based learning sudah banyak dilakukan antara lain Ali (2013), susdarwati (2016), nayank (2018) dan masih banyak penelitian yang menggunakan model problem based learning dengan hasil pembelajaran yang baik. Dengan demikian model problem based learning ini dapat dikembangkan lagi untuk merekomendasikan proses pembelajaran yang aktif.

Tahap perencanaan dalam penelitian dan pengembangan ini yang juga turut mendukung keberhasilan pembuatan perangkat pembelajaran. Hasil perencanaan ini mampu menghasilkan aspekaspek penting dalam pembelajaran seperti, pembuatan rumusan indikator pencapaian kompetensi, pembuatan analisis pengetahuan dan konsepsi topik laju reaksi, penyelarasan langkah-langkah pembelajaran saintifik 5M dalam model pembelajaran problem based learning, sinergisitas model problem based learning yang mengakomodasi langkah-langkah pendekatan saintifik 5M pada perangkat pembelajaran (RPP, LKS, teks materi pelajaran, dan instrumen penilaian) dan rancangan validasi perangkat pembelajaran. Pembuatan dan pengembangan produk memperhatikan mengacu pada sinergitas perangkat pembelajaran. Sinergitas dari form perangkat pembelajaran sebagai acuan agar tetap selaras dan konsisten agar seluruh perangkat pembelajaran tetap konsisten mengacu pada pendekatan saintifik yang diamanatkan oleh kurikulum 2013 melalui penalaran induktif dengan model problem based learning dengan karakteristik 5 m pada perangkat pembelajaran dijabarkan seperti halnya. Karakteristik perangkat pembelajaran pada topik laju reaksi dengan penalaran induktif meliputi RPP, LKS, teks materi pelajaran, yakni sinergis dan konsisten mengikuti tahap-tahap pendekatan saintifik dengan model problem based learning. Karakteristik perangkat pembelajaran untuk masing-masing tahapan kegiatan 5M dengan model problem based learning melalui penalaran induktif sebagai berikut tahap pertama fase sintak model problem based learning yakni orientasi siswa terhadap masalah yang meliputi menjelaskan tujuan pembelajaran.

Tahap pertama dan kedua dalam kegiatan $5 \mathrm{M}$ adalah mengamati dan menanya pada model problem based learning terdapat pada sintak mengorganisasikan siswa untuk belajar. Pada fase ini Kegiatan pembelajaran dilakukan berdasarkan sintaks pembelajaran model problem based learning dalam RPP yang telah dikembangkan dan mengacu pada pendekatan saintifik. Pada pertemuan pertama guru membahas LKS yang diberikan kepada siswa. sebelum pembelajaran tersebut berlangsung guru sudah memberikan LKS sebagai tugas pra pembelajaran untuk mengerjakan M1 s/d M3. Pembelajaran yang terjadi pada pertemuan pertama guru mengarahkan siswa untuk memahami teks pengantar (berisi fenomena). Ketika mengamati masih memunculkan kebingungan bagi siswa bahkan masih sulit memahami masalah atau menemukan masalah pada saat mengidentifikasikan masalah dari fenomena yang disajikan. Hal ini lebih lanjut lagi dipengaruhi karena pada pembelajaran sebelumnya siswa masih cendrung menerima informasi dari guru saja tidak aktif dalam mencari informasi-informasi baru. Lebih lanjut lagi siswa kurang memahami perintah dan tujuan dari kegiatan pembelajaran yang sudah dijelaskan ketika mengamati suatu masalah. Hal ini didukung oleh Paidi (2011: 197) menyatakan bahwa dengan permasalahan yang ada membutuhkan analisis, upaya kooperatif, serta pemikiran dari berbagai sudut pandang untuk dapat mengenal dan memecahkanya dengan baik. Pada tahap mengamati pertemuan pertama siswa lebih banyak diberi bimbingan dari pada siswa sendiri yang menemukan langsung masalah-masalah. Fase mengamati terus dilatih kepada siswa untuk mencapai tujuan dari pembelajaran dan karakteristik dari model yang dikembangkan. Dimana masalah-masalah yang ditemukan siswa merupakan starting point dalam melaksanakan pembelajaran dengan model problem based learning. Fase mengamati setiap pertemuannya mengalami peningkatan walau beberapa siswa masih sulit dalam mengamati masalah yang ada, ketercapain dalam fase mengamati ini sangat baik karena adanya peningkatan dari siswa dan masalah-masalah yang ada mampu ditemukan sendiri oleh siswa. melakukan mengamati batasan masalah dari hasil masalah-masalah yang sudah teridentifikasi oleh siswa sendiri. Batasan masalah mengacu pada tujuan pembelajaran yang akan dipecahkan dari banyak masalah yang dimunculkan siswa. Selanjutnya siswa membuat rumusan masalah dari batasan masalah yang sudah dipilih oleh siswa. Rumusan masalah dirancang untuk siswa sendiri mampu memecahkan masalah tersebut. 
Tahap ketiga dalam kegiatan $5 \mathrm{M}$ adalah mengumpulkan data, fase mengumpulkan data siswa secara aktif membaca berbagai sumber dan siswa bekerjasama dalam menemukan hipotesis yang menjadi dugaan semntara sebelum siswa memecahkan masalah secara teoritis. Karena model problem based learning selaras dengan penalaran induktif siswa mengumpulkan data dari pengamatan-pengamatan secara langsung yang terjadi dalam dunia nyata. Selama kegiatan pembelajaran berlangsung, sebagian besar peserta didik aktif mencari tahu dengan menggunakan sumber lain. Sehingga dari kegiatan tersebut terjadi diskusi kelompok yang aktif dan saling melengkapi dengan segala informasi yang mereka temukan pada sumber lain. Susanto (2015) menyatakan bahwa implementasi problem based learning ditandai dengan adanya kerjasama antar peserta didik yang akan memberikan motivasi untuk teribat dalam tugas dan meningkatkan kesempatan untuk bertukar pikiran serta melakukan dialog untuk mengembangkan kecakapan sosial. Setelah membuat hipotesis siswa membuat rancangan percobaan dari menentukan variable-varibel dari hipotesis dan menentukan alat dan bahan serta prosedur kerja untuk membuktikan hipotesis. Pada sintak model problem based leraning fase mengumpulkan data tersebut termasuk kedalam membimbing penyelidikan individu atau kelas.

Tahap keempat kegiatan $5 \mathrm{M}$ adalah mengasosiasi. Pada tahap ini masih berada sintak model problem based learning membimbing penyelidikan individu atau kelas. Pada tahap mengasosisasi siswa melakukan pembuktian dari hipotesis yang siswa sudah temukan dan menjawab pertanyaan sehingga membuat kesimpulan dari hasil percobaan yang sudah diperoleh dengan membuat laporan atau dalam bentuk multimedia seperti power point. Tahap terakhir dalam fase $5 \mathrm{M}$ adalah mengkomunikasikan. Pada tahap mengkomunikasikan ini siswa secara aktif menyampaikan hasil dari percobaan yang sudah dilakukan dan menggkomunikasikan dengan baik setiap pertemuan yang berlangsung. Pada RPP, guru menuntun peserta didik untuk mengkomunikasikan hasil pembelajaran dan kesimpulan yang telah didapatkan. Pada LKS terdapat tagihan untuk mengkomunikasikan hasil pembelajaran dan kesimpulan yang didapatkan dari kegiatan percobaan dan diskusi. Hal ini berfungsi untuk mengevaluasi dan mengklarifikasi kembali hasil pemecahan masalah yang diperoleh siswa.

Keterampilan pemecahan masalah di kelas perlakuan menunjukkan bahwa model problem based learning selain dapat meningkatkan keterampilan pemecahan masalah juga membantu peserta didik dalam mengkonstruksi berbagai permasalahan yang ada menjadi pengetahuan baru yang mudah dipahami oleh peserta didik. Amisyah, Sarong, \& Nurmaliah (2013: 91) menyatakan bahwa kemampuan pemecahan masalah akan mendorong semangat dan keinginan peserta didik untuk belajar. Chakravarthi \& Vijayan (2010: 41-42) juga melihat bahwa model pembelajaran problem based learning dapat membantu peserta didik menjadi pembelajar yang mandiri, bertanggung jawab dalam mengenal dan mengejar tujuan belajar mereka serta mengarahkan mereka untuk belajar sepanjang hayat. Dengan demikian, hal tersebut akan membuat peserta didik memiliki retensi atau daya ingat yang lebih lama terhadap pengetahuan yang dimilikinya. Hal ini sejalan dengan pendapat dari Fogarty (1997: 2) yang menyatakan bahwa PBL merupakan model kurikulum yang dirancang untuk mempelajari masalah kehidupan nyata, bersifat terbuka, dan menghasilkan banyak penafsiran atau bersifat kompleks. Gregory \& Chapman (2013: 171) lebih lanjut menyatakan PBL menyediakan peserta didik masalah yang menantang, kemudian mereka menggunakan informasi dan proses dalam situasi yang nyata untuk memecahkan masalah tersebut.

Keberhasilan siswa dalam menuntaskan pembelajaran ini diperoleh karena ketersediaan perangkat pembelajaran yang meliputi RPP, LKS, Teks materi yang berkualitas dan mengacu pada Kurikulum 2013. Selain itu keberhasilan juga diperoleh karena terlaksananya sintaks dari problem based learning dengan baik. Selama kegiatan pembelajaran di kelas perlakuan suasana pembelajarannya sangat aktif dan semangat.

Secara umum, perangkat pembelajaran yang telah dikembangkan layak untuk diterapkan pada proses pembelajaran yang menerapkan kurikulum 2013. Hal ini dikarenakan perangkat pembelajaran yang telah dikembangkan memiliki tingkat validitas yang memadai dan tingkat keterbacaan yang baik. Mayoritas butir-butir penilaian dari keseluruhan aspek-aspek perangkat pembelajaran mendapatkan penilaian baik dan sangat baik. Selain itu, perbaikan juga dilakukan pada perangkat pembelajaran yang didasarkan pada masukan dari validator pada lembar penilaian dan perangkat pembelajaran. Perbaikan terhadap perangkat pembelajaran melalui penilaian dan masukan dari validator dapat menyempurnakan perangkat pembelajaran dan berkontribusi pada baiknya valliditas perangkat pembelajarannya.

Karakteristik dari perangkat pembelajaran yang telah dikembangkan adalah sinergis dan konsisten dalam menerapkan pendekatan saintifik penalaran induktif dengan model problem based learning. Hal ini didukung oleh pernyataan-pernyataan eksplisit dari validator-validator. Praktisi yang pertama (G1), menyatakan, "Secara umum perangkat pembelajaran laju reaksi yang dikembangkan telah tersusun dengan sangat baik, dan telah memperhatikan pola pembelajaran seperti yang dituntut kurikulum 2013". Hal ini juga didukung oleh G2. Dukungan yang kuat juga datang dari ahli isi (D2), yang 
menyatakan, "Perangkat pembelajaran yang dikembangkan sudah komprehensif dan sesuai dengan penalaran induktif dengan model problem based learning".

Perangkat pembelajaran laju reaksi dengan model problem based learning dengan penalaran induktif yang dikembangkan memiliki keunggulan-keunggulan. Perangkat pembelajaran ini merupakan salah satu cara untuk menerapkan kurikulum 2013 secara komprehensif. Kurikulum 2013 mengisyaratkan pembelajaran hendaknya dilaksanakan dengan pendekataan induktif (Permendikbud Nomor 24 tahun 2016). Perangkat pembelajaran yang sudah dikembangkan secara sinergis telah menerapkan pendekatan saintifik penalaran induktif model problem based learning.

Sajian-sajian fenomena awal yang secara sinergis terdapat di setiap perangkat pembelajaran memungkinkan siswa untuk lebih memahami tiap sub-materi yang akan dipelajari. Hal ini didukung oleh Johnstone (1991), yang menyatakan pembelajaran kimia hendaknya mencakup tiga aspek, makroskopis, mikroskopis dan simbolis. Fenomena awal merupakan contoh aspek makroskopis terkait materi yang dipelajari. Hal serupa juga diungkapkan Subagia (2014), yang menyatakan mengaitkan pelajaran kimia dengan eksistensi kimia dalam kehidupan sehari-hari merupakan salah satu cara menuju paradigma baru pembelajaran kimia SMA untuk pengetahuan kimia yang baik dan benar.

Konsistensi penerapan pendekatan induktif dari perangkat pembelajaran yang dikembangkan dapat melatih keterampilan berpikir siswa. Dengan terbiasanya siswa berpikir induktif maka siswa dapat menguasai salah satu keterampilan ilmiah. Penguasaan keterampilan berpikir dapat menghindarkan siswa dari belajar yang sifatnya menghafal (Sudria, et al., 2013). Selain itu penguasaan keterampilan ilmiah merupakan elemen dasar pencapaian tujuan pendidikan nasional (Subagia, 2013).

\section{SIMPULAN DAN SARAN}

Berdasarkan hasil dan pembahasan yang telah dilakukan, dapat dibuat simpulan sebagai berikut : 1) mendeskripsikan hasil karateristi perangkat pembelajaran dengan model problem based learning melalui penalaran induktif pada topik laju reaksi. 2) Hasil validitas dan uji keterbacaan perangkat pembelajaran menunjukkan tingkat validitas yang memadai dan tingkat keterbacaan yang baik. Mayoritas butir-butir penilaian dari keseluruhan aspek-aspek perangkat pembelajaran mendapatkan penilaian baik dan sangat baik. 3) Perangkat pembelajaran yang dikembangkan efektif mendukung pembelajaran sains yang signifikan, dilihat dari perolehan belajar siswa kelas XI SMA Negeri 4 Singaraja antara skor pretest 23,27 dan postest 65,18, serta Normalitas Gain Score 0,55 tergolong sedang. Selain itu, adanya perkembangan kinerja proses $5 \mathrm{M}$ siswa yang dinilai dari LKS cenderung mengalami peningkatan dan adanya apresiasi/ respon yang baik dari siswa selama mengikuti pembelajaran dengan menggunakan perangkat pembelajaran yang dikembangkan.

\section{DAFTAR PUSTAKA}

American Association for the Advancement of Scinece (AAAS). 1993. Benchmarks for Science Literacy: Project 2061. NewYork : Oxford University Press.

Amisyah, S., Sarong, M.A., \& Nurmaliah, C. 2013. Upaya Peningkatan Hasil Belajar Kognitif melalui Model Problem Based Learning. Jurnal Biotik,

$\mathrm{I}(2), 67-136$.

Arends, R. I. 2008. Belajar Untuk Mengajar (Terjemahan Helly Prajitno Soetjipto \& Sri Mulyantini Soetjipto). New York: MeGraw Hils.

Arikunto, S. 2010. Dasar-Dasar Evaluasi Pendidikan. Jakarta: Bumi Aksara.

Arviani, V. 2011. Identifikasi Pemahaman Konsep Laju Reaksi Siswa Kelas XI SMA Brawijaya Smart Schoo. http://karyailmiah.um.ac.id/. Diakses tanggal 4 september 2018

Bruner, J. (1966. Toward a theory of instruction. Cambridge, MA: Belknap Press of Harvard University Press.

Borg, W. R., \& Gall, M. D. 1989. Educational Research: An Introduction. New York: NY Longman.

Cakmaci, G., Leach, J. \& Donnelly, J. 2006. Students'ideas about reaction rate and its relationship with concentration or pressure. International Journal of Science Education, 28(15), 1795-1815.

Candiasa, I M. 2010. Pengujian Instrumen Penelitian Disertai Aplikasi ITEMAN dan BIGSTEPS. Singaraja: Unit Penerbitan Universitas Pendidikan Ganesha.

Carin, A. A., \& Sund, R. 1975. Teaching Science Through Discovery. Ohio: Charles E. Meril Publisher.

Chiappetta, E. L., Koballa, T. R., \& Collette, A. T. 1998. Science Instruction in the Middle and Secondary School, 4th Edition. Upper Saddle River, NJ: Merril/Prentice Hall.

Dick, W., \& Carey, L. 1990. The Systematic Design of Instruction third Edition. United State: HarperCollinsPublisher.

Felder, R. M., \& Silverman, L. K. 1988. Learning and Teaching Styles in Engineering Education. Engr. Education, 78(7), 674-681. 
Fogarty, R. 1997. Problem Based Learning and Other Curiculum Moels for the Multiple Intelligencess Classroom. Arlington Heights Illionis: Sky Light.

Hake, R, R. 1999. Analyzing Change/Gain Score. AREA-D American Education Research Association's Devision.D, Measurement and Reasearch Methodology

Hind , A., Leach, J., \& Ryder, J. 2001. Teaching about the Nature of Scientific Knowledge and Investigation on AS/A Level Science Course. West Yorkshire: The Nuffield Foundation .

Indriani, N. P. 2014. Siklus Belajar Deduktif-Hipotetik untuk Mendukung Efektivitas Belajar Proses Sains Siswa. Skripsi tidak dipublikasikan. Singaraja: Universitas Pendidikan Ganesha.

Johnstone, A. H. 1991. Why is Science Difficult to Learn? Things are Seldom What They Seem. Journal of Computer Assisted Learning, 75-83.

Koyan, I.W. 2012. Statistik Pendidikan Teknik Analisis Data Kuantitatif. Singaraja: Undiksha press.

OECD. 2016. PISA 2015 Result in focus. Diakses pada 20 desember 2017 dari https://www.oecd.org/PISA

Kemendikbud. 2016. Peraturan Mentri Pendidikan Dan Kebudayaan Nomor 24 Tahun 2016 Tentang Kompetensi Inti Dan Kompetensi Dasar Pelajaran Pada Kurikulum 2013 Pada Pendidikan Dasar Dan Pendidikan Menengah.

Subagia, I. W. 2013. Implementasi Pendekatan Ilmiah dalam Kurikulum 2013 untuk Mewujudnyatakan Tujuan Pendidikan Nasional. Seminar Nasional FMIPA Undiksha III (hal. 16-29). Singaraja: Universitas Pendidikan Ganesha.

Sudria, I. B., Kartowasono, N., Frieda, N., \& Sya'ban, S. 2013. Pengembangan Perangkat Pembelajaran Kimia dengan Pendekatan Berpikir Induktif dan Deduktif. Laporan Penelitia, tidak dipublikasikan.

Sudria, I.B.N. \& Sya'ban, S,. 2015. Pengembangan Perangkat Pembelajaran dengan Pola Berpikir Induktif dan Deduktif untuk Pembinaan Keterampilan Saintifik Siswa Sekolah Menengah. Laporan Penelitian tidak dipublikasikan.

Suja, I. W. 2007. Kajian Pustaka: Keterampilan Proses Sains dengan Pendekatan Sains Teknologi Masyarakat dan Lingkungan. Singaraja: Universitas Pendidikan Ganesha.

Susdarwati, dkk. 2016. Pengembangan Perangkat Pembelajaran Fisika Berbasis Problem Based Learning (PBL) Pada Materi Hukum Newton dan Penerapannya kelas X SMA 2 Mejan. fkip.uns.ac.id/index.php/sains Universitas Sebelas Maret.

Tan, O. S. 2003. Problem Based Learning Innovation. Singapore: Thomson Learning.

Thomond, P. N. 2004. Exploring and Describing Management Action for the Pursuit of Distruptive Innovation. Doctor Thesis. Cranfield University. Diakses 2 Januari 2018 dari space.lib.cranfield.ac.uk/ .../ P.\%20 Thomond\% 20Thesis\%202004.pdf. 